\title{
,auk \\ Changes in Watering Frequency Stimulate Differentiated Adaptive Responses among Seedlings of Different Beech Populations
}

\author{
Georgios Varsamis ${ }^{1, *}$, George C. Adamidis ${ }^{2}{ }^{\mathbb{D}}$, Theodora Merou ${ }^{1}$, Ioannis Takos ${ }^{1}$, Katerina Tseniklidou ${ }^{1}$, \\ Panayiotis G. Dimitrakopoulos ${ }^{3}$ (i) and Aristotelis C. Papageorgiou $4, * \mathbb{B}$
}

check for

updates

Citation: Varsamis, G.; Adamidis,

G.C.; Merou, T.; Takos, I.; Tseniklidou,

K.; Dimitrakopoulos, P.G.;

Papageorgiou, A.C. Changes in Watering Frequency Stimulate Differentiated Adaptive Responses among Seedlings of Different Beech Populations. Biology 2022, 11, 306. https://doi.org/10.3390/ biology11020306

Academic Editor: Dorothea Bartels

Received: 20 December 2021

Accepted: 11 February 2022

Published: 14 February 2022

Publisher's Note: MDPI stays neutral with regard to jurisdictional claims in published maps and institutional affiliations.

Copyright: (C) 2022 by the authors. Licensee MDPI, Basel, Switzerland. This article is an open access article distributed under the terms and conditions of the Creative Commons Attribution (CC BY) license (https:// creativecommons.org/licenses/by/ $4.0 /)$.
1 Department of Forest and Natural Environment Sciences, International Hellenic University, 66100 Drama, Greece; thmerou@for.ihu.gr (T.M.); itakos@for.ihu.gr (I.T.);

katerina.tseniklidou@gmail.com (K.T.)

2 Section of Plant Biology, Department of Biology, University of Patras, Rio, 26504 Patras, Greece; adamidis@upatras.gr

3 Biodiversity Conservation Laboratory, Department of Environment, University of the Aegean, 81100 Mytilene, Greece; pdimi@env.aegean.gr

4 Department of Molecular Biology and Genetics, Democritus University of Thrace, Dragana, 68100 Alexandroupolis, Greece

* Correspondence: gvarsami@fmenr.duth.gr (G.V.); apapage@mbg.duth.gr (A.C.P.); Tel.: +30-25210-60473 (G.V.); +30-25510-30494 (A.C.P.)

Simple Summary: Future precipitation changes are expected to affect plant populations' adaptive responses. In southern Europe, annual precipitation is expected to decline and become unpredictable with occasional extreme rainfall events. Although there are many studies investigating water deficit effects in beech populations, they mainly refer to water withholding and rewatering or limited watering for prolonged periods. There is a lack of information considering the effect of simulated changes in monthly precipitation distribution on plants. In our study, we aimed to elucidate whether simulated distribution differences in monthly precipitation, expected to prevail in 2050, affects the response of various adaptive traits in beech seedlings originating from sites with contrasting climatic conditions. We found significant population differences according to watering interactions in most of the stem anatomical traits, but only for leaf circularity regarding the morphological traits. Our results indicate that beech populations in the southernmost region of their European distribution may demonstrate high variability in adaptive responses towards climate change conditions.

Abstract: Seasonality, rather than annual precipitation levels, is expected to affect the adaptive responses of plant populations under future climate change. To estimate adaptive traits' variation, we conducted a common garden experiment with two beech populations from contrasting climatic origins (Evros with longer drought intervals during summer and higher precipitation seasonality, and Drama representing a more temperate ecosystem). We simulated two different watering treatments (frequent vs. non-frequent) on beech seedlings, according to predicted monthly precipitation levels expected to prevail in 2050 by the CSIRO MK3.6 SRESA1B model, considering as reference area a natural beech stand in Mt. Rodopi, Greece. A series of morphological and stem anatomical traits were measured. Seedling survival was greater for the Evros population compared to that of Drama under non-frequent watering, while no difference in survival was detected under frequent watering. Leaf morphological traits were not generally affected by watering frequency except for leaf circularity, which was found to be lower under non-frequent watering for both populations. Stomata density in leaves was found to be higher in the Evros population and lower in the Drama population under nonfrequent watering than frequent. Stem anatomical traits were higher under non-frequent watering for Evros but lower for the Drama population. Multivariate analyses clearly discriminated populations under non-frequent rather than frequent watering, indicating genetic adaptation to the population's environment of origin. 
Keywords: beech; stem anatomy; adaptive traits; seedling morphology; precipitation seasonality; climate change

\section{Introduction}

The ongoing climate change is expected to cause prolonged drought periods and changes in seasonal precipitation patterns across the Mediterranean basin, having profound effects on range expansion, adaptive potential and survival dynamics of wild plant populations [1,2]. The above effects can significantly impact the mortality rate of individual plants and cause losses in primary productivity and eventually declines of whole ecosystems [3,4].

One of the plant species that are expected to be mostly affected by climate change is the European beech (Fagus sylvatica L.), a dominant forest tree species in Europe that is considered sensitive to extended drought summers [3,5-11]. Effects of adverse climate conditions connected to climate change on beech forests have been already reported since the beginning of the 21st century [1,12]. During summers with extreme drought events (e.g., 2003 and 2018), most European beech populations were negatively affected [11,13], but the ones growing in Greece were, interestingly, less affected during the summer drought of 2003 [14]. This indicates the existence of intra-specific variation in adaptive traits, defining potential alternative survival strategies among populations growing under different environmental conditions [15-19].

In order to evaluate these different strategies among beech populations, a study of adaptive traits under conditions of water deficit in schemes of common environment experiments is required. Traditionally, such common garden experiments have been utilized to evaluate the performance of forest tree populations of different origins, adapted to different environmental conditions (provenances). In these experiments, the same environmental pressure is applied and different adaptive mechanisms can then be revealed among populations of the same tree species, while genes of adaptive significance can also be identified making this methodology substantial for designing management and conservation plans [20,21]. Additionally, data derived from common garden experiments can be used as base reference for model prediction processes regarding species populations parameters such as growth and distribution under future projected scenarios [22].

Plants experiencing prolonged drought intervals between precipitation events usually respond directly to environmental stress by modifying various aspects of their phenology, physiology, morphology and/or anatomy [18,23-29]. Additionally, plant populations originating from different locations often appear to modify stomata parameters such as size or density, as a result of adaptation to the varying levels of precipitation on their original site [30-32].

Plasticity of morphological traits, at the population level, under environmental pressure (e.g., drought) is a common adaptive response [33]. Leaf size and shape are among the most plastic traits; in broadleaved trees, under water deficit, leaf size is reduced and leaves usually become narrower $[32,34,35]$. As carbon production is reduced under water deficit due to the decrease in photosynthesis rate, plants change their allometric traits such as specific leaf area (SLA), root to shoot ratio and biomass allocation, to adjust growth under the deficit pressure and ensure survival [36-38]. Important plastic responses occur in plant anatomical traits as well. Plants under water deficit modify xylem or phloem structural traits, such as conduit diameter or pit membrane characters, or produce more conduits in the same growth period [39-44].

Apart from the vascular (phloem, xylem) tissues, both ground (cortex, pith) and dermal (phellem) tissues, which provide carbon storage and mechanical support, can change when plants experience a water deficit. Phellem (later named outer bark), which is the main stem protective tissue, usually becomes thicker under water deficit to reduce stem transpiration, maintain hydraulic balance and protect stem photosynthetic activity [45-47]. 
Pith and cortex, which consist of parenchymatous cells that possess storage roles of NSCs in sink organs, while regarding cortex chlorenchyma contributions to the overall carbon fixation through stem photosynthesis, can also be affected by water deficiency [48-53].

Common garden experiments investigating the consequences of imposed water deficits on seedlings/saplings of woody plant species usually apply a combination of water withholding followed by rewatering treatments for one or more time periods [10,54-59], or continuous water stress (limited watering) for prolonged drought periods, or, also sometimes, water suspension until seedling desiccation [59-63]. However, it is generally accepted that the most striking consequence of climate change is the increased intensity and frequency of extreme weather events [64]. These events are related not necessarily to decreased precipitation, but to shifts in temporal precipitation patterns (e.g., periods of extended drought followed by heavy rainfall events). Common garden experiments simulating this kind of extreme weather events, based on future projected climatic conditions, to study plant adaptive traits are generally lacking and are highly essential to the good practice of forest management.

In our study, we established a six-year common garden experiment where beech seedlings originating from two populations growing under contrasting environmental field conditions were subjected to simulated irrigation frequency treatments according to the monthly precipitation levels expected to prevail in 2050. We aimed to assess whether the tested beech provenances would respond differently under different precipitation frequencies regarding anatomical and morphological traits. We expected the beech population originating from an area experiencing increased summer drought to have a higher adaptive capacity to extreme precipitation patterns.

\section{Materials and Methods}

\subsection{Selected Populations and Plant Material}

Two natural beech populations growing in locations with different climatic conditions in northeastern Greece, Evros and Drama, were selected for this study (Figure 1). Evros lies on the eastern side of the Greek part of the Rodopi mountain range and is characterized by a Meso-Mediterranean (attenuated) climate type with cold and moist winters, but warm summer periods of increasing drought duration. Drama is located on the western edge of the Rodopi mountains and resembles a Sub-Mediterranean climate type with high continentality, severe winters and generally less warm summers with a smaller duration of droughts. Bioclimatic factors for the selected populations are displayed in Table S1. Although Evros receives higher levels of annual precipitation compared to Drama, Evros demonstrates higher precipitation seasonality. More specifically, precipitation of the coldest quarter is higher in Evros as compared to Drama. This shows that Evros receives most of its annual precipitation during winter. At the same time, precipitation of both the driest month and the warmest quarter is lower in Evros. Finally, the drought period lasts longer in Evros and the index is higher there in contrast to Drama (Table S1). These beech populations (Drama and Evros) were included in previous genetic studies using neutral molecular markers and were found to differ $[65,66]$. Most interestingly, comparisons between the same two beech populations in common garden experiments have revealed significant differences in adaptive traits of seedlings in bud burst phenology [18] and seed germination attributes [19]. 


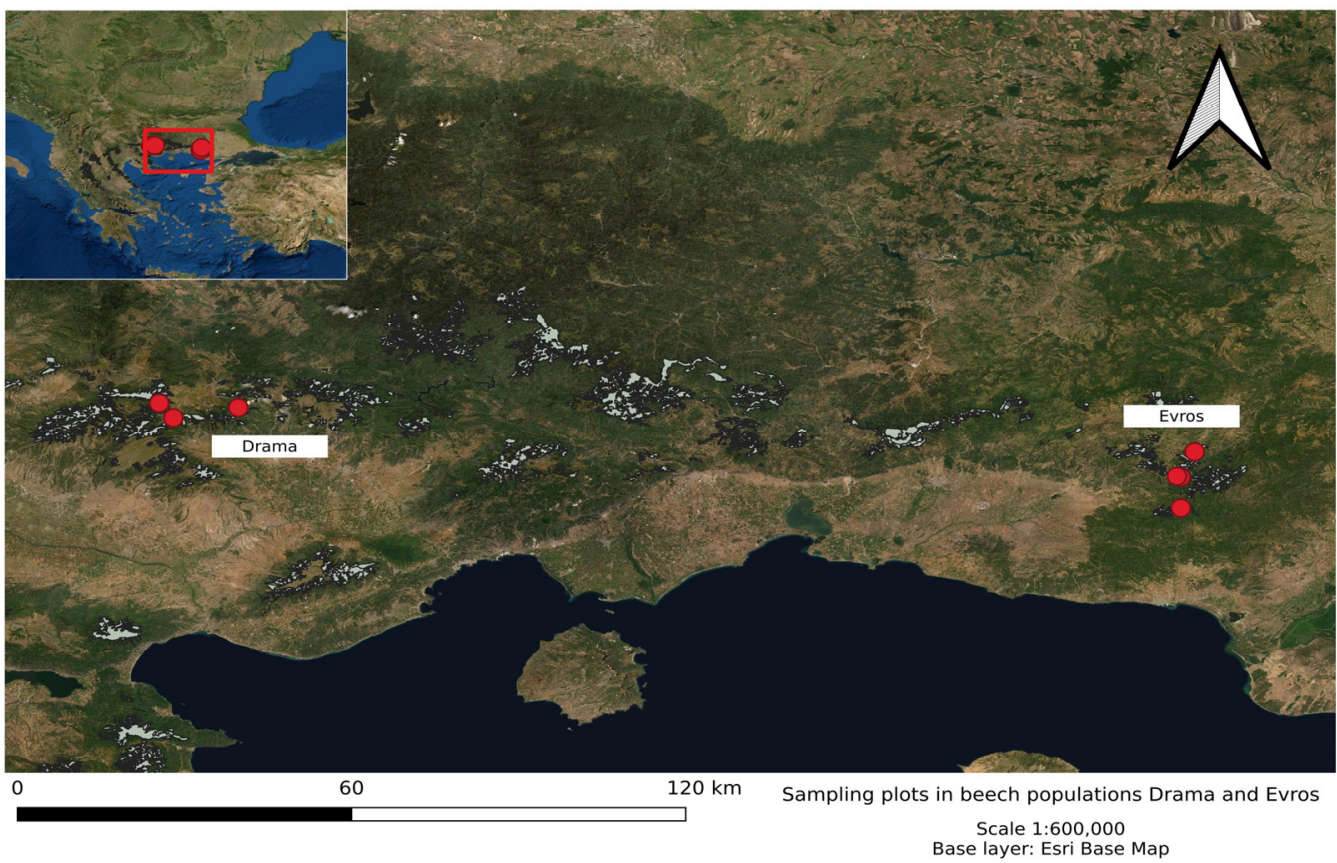

Figure 1. Map with the location of sampling plots in the beech populations Drama and Evros in NE Greece. Light-gray shading indicates the area covered by beech forests in Greece.

Within each population, four representative sampling plots were selected, but finally one plot from Drama was excluded from the trial due to the abnormal development of the produced seedlings, according to ISTA rules [67]. Within each plot (a total of four plots from Evros and three plots from Drama), seeds were collected from 30 individual trees, in October 2012. Collected seeds were cleaned, subjected to cold moist stratification at $0{ }^{\circ} \mathrm{C}$ for 90 days and finally germinated under alternate temperatures $\left(+25^{\circ} \mathrm{C} /+15^{\circ} \mathrm{C}\right)$ and photoperiod conditions ( $8 \mathrm{~h} / 16 \mathrm{~h}$, light/dark). Germinants were initially planted in pots filled with Sand:Turf:Perlite at 4:2:1 ratios, respectively. The produced seedlings were monitored for one month and those that developed abnormally were discarded [67].

\subsection{Experimental Design and Simulated Climate Change Precipitation Schemes}

The effect of future climate change conditions on adaptive traits of beech seedlings was investigated through a six-year simulation experiment established in two plant growth chambers. The reference area for the simulation of the climate conditions was a natural beech forest located in the Drama region $\left(41^{\circ} 17^{\prime} 29.47^{\prime \prime} \mathrm{N}, 23^{\circ} 55^{\prime} 17.69^{\prime \prime}\right.$ E). Future monthly temperature and precipitation data for the year 2050 under the CSIRO MK3.6 (SRES A1B) model were downloaded from "climond.org" database in the .GRD format and processed to produce a spreadsheet with these variables on a monthly basis $[68,69]$ (Table S2). Seedlings were grown under a common temperature scheme and two different watering treatments (frequent watering (FR): watering every 7 days; and non-frequent watering (NF): watering every 20 days) simulating different monthly precipitation patterns. The amount of watering for each month of the experiment was the same for both watering treatments and corresponded to the estimated rainfall of the specific month under the CSIRO MK 3.6 and SRES A1B. The simulated experimental design is also described in full detail in Varsamis et al. [18]. The experiment ended in October 2019 and the seedlings were subjected to the destructive measures described below. The seedlings' final survival was calculated on a percentage basis.

\subsection{Morphological and Anatomical Traits}

Three fully developed leaves per seedling were collected in July 2019 and digitally scanned on a portable hp Scanjet 5590 flatbed scanner device (HP Development Company, 
L.P.). The area of the lamina was measured alongside with additional morphological traits using Image J v. 1.50i (http:/ /imagej.nih.gov/ij, accessed on 12 January 2022, USA). The traits measured were the angle between leaf tip and base, the number of secondary veins, leaf length and width as well as leaf circularity (Table 1). In the middle of the abaxial lamina, stomatal density was measured using the nail varnish imprinting method [70]. Three neighboring images per leaf slide were captured under 250× magnification on a Nikon microscope, the mean stomatal number per $\mathrm{mm}^{2}$ leaf area was calculated for every leaf and then the mean stomatal number of the three leaves was further calculated [62,70]. Then, individual leaf dry weight was determined after oven-drying at $70^{\circ} \mathrm{C}$ for $24 \mathrm{~h}$ [71]. Specific leaf area was calculated as the ratio of the leaf area to the dry weight, to describe the balance of carbon acquisition and use [72]. Finally, leaf thickness was indirectly estimated by calculating specific leaf area and leaf dry matter content following Vile et al. [73].

Table 1. Definition of the measured traits.

\begin{tabular}{|c|c|}
\hline Trait & Description \\
\hline Specific leaf area (SLA) & The ratio of leaf area to dry weight. \\
\hline Leaf dry matter content (LDMC) & The ratio of leaf fresh weight to its dry weight. \\
\hline Leaf thickness & The estimated leaf lamina thickness. \\
\hline Leaf length & The length of leaf lamina. \\
\hline Leaf width & The width of leaf lamina at its maximum. \\
\hline Leaf base angle & The angle of leaf lamina base. \\
\hline Leaf tip angle & The angle of leaf lamina tip. \\
\hline Number of leaf secondary veins & Number of first-class veins. \\
\hline Leaf circularity & The ratio of area to perimeter of leaf. \\
\hline Shoot length & The length from the root collar to the apical bud. \\
\hline Shoot dry weight & The shoot weight after drying in an oven. \\
\hline Root area & The projected area of the whole seedling root system. \\
\hline Root dry weight & The root system weight after drying in an oven. \\
\hline Section area & Total projected area of the produced stem section. \\
\hline Phellem length & Length of the outer plant suberized epidermis. \\
\hline Cortex length & $\begin{array}{l}\text { Length of the tissue layer between epidermis and phloem } \\
\text { tissue. }\end{array}$ \\
\hline Phloem length & Length of the tissue layer between cortex and xylem. \\
\hline Xylem length & Length of the tissue layer between phloem and pith. \\
\hline Pith length & Maximum length of the pith \\
\hline Stomatal density & Density of stomata number in the middle leaf lamina part. \\
\hline Number of pith rays & $\begin{array}{l}\text { The number of the rays that connect the vascular system } \\
\text { (xylem, phloem) with the pith. }\end{array}$ \\
\hline
\end{tabular}

In October 2019, after the current growth period had ended, the seedlings were removed from the pots and separated into their shoot and root parts by cutting the seedlings with a pair of scissors at the root collar. Shoot length was measured with a ruler, while the root (including primary, seminal and lateral roots) was scanned on a flatbed scanner device and the root surface area was measured using Image J. Then, both shoot and root dry weights were measured after oven-drying at $70^{\circ} \mathrm{C}$ for $24 \mathrm{~h}$. Prior to oven-drying, a $1 \mathrm{~cm}$ shoot piece was cut, fixed in a mixed solution of $80 \%$ ethanol ( $100 \%$ stock solution) and $20 \%$ glycerol ( $70 \%$ stock solution) that was renewed daily for 5 days and subjected to sectioning at a cryotome at $30 \mu \mathrm{m}$ (modified protocol from Jupa et al. [74]). The sections 
were then mounted to a glass slide at a thermoplate at $37^{\circ} \mathrm{C}$ for 20 min using Haupt's adhesive recipe [75]. Afterwards, they were immersed in $0.1 \%$ toluidine blue for two minutes, washed with distilled water and dehydrated in ascending ethanol series [76]. Finally, in each section in the glass slide, a drop of $70 \%$ glycerol and a coverslip were added. Sections were examined under $100 \times$ magnification on a microscope. The measured stem adaptive traits were: the section area, the length of phellem, cortex, phloem and xylem, and the pith length alongside the number of pith rays [77] (Table 1).

\subsection{Statistical Analyses}

Mean trait values were calculated for all traits at the population level. Normality was checked with the Kolmogorov-Smirnov test and all traits had values following the normal distribution, apart from the number of pith rays, the root area, the number of secondary leaf veins and the leaf length. The normality of the latter traits was corrected by using arcsine transformation. Differences in trait mean values were checked with an independent $t$-test for all variables except for the number of secondary leaf veins, where the Mann-Whitney test was used.

A principal component analysis (PCA) using the "FactoMineR" package of R [78] was performed separately for each of the watering treatments. Finally, mixed model analysis was performed using the SPSS v.19 software (SPSS Inc., Chicago, IL, USA) considering individual seedlings as a random factor and watering treatment and population as fixed factors. The maximum likelihood was used as an estimator of model parameters.

\section{Results}

\subsection{Seedling Survival}

The percentage of survived seedlings differed between populations under non-frequent watering. Seedlings originating from Evros presented significantly higher survival than those from Drama (Figure 2). On the other hand, no significant differences between populations were observed under frequent watering.

\subsection{Differences between Watering Treatments}

Among all traits, leaf circularity and phloem length were the only traits found to differ significantly between non-frequent and frequent watering treatments (Table 2). However, when the interaction between population and treatment was considered, different trends in changes between treatments were described at the level of each population (Table 2 and Table S3). Both in Evros and Drama, leaf circularity values were higher under frequent watering, but this difference was greater in Drama. Additionally, only the seedlings of Evros presented higher root and shoot dry weight under non-frequent watering. Regarding stem anatomical traits, seedlings from Evros presented higher values under non-frequent watering, except from the number of pith rays, where no difference between the watering treatments emerged. In Drama, seedlings under non-frequent watering presented lower section area, phloem and xylem length, but higher stomatal number.

\subsection{Differences between Populations}

Mixed model analysis revealed significant differences in most of the measured traits between the studied populations. Among the leaf morphological traits and under nonfrequent watering, leaf circularity and leaf length were significantly different between the populations (Table 2), while no significant differences were found at any of the leaf morphological traits under frequent watering. In Evros, leaf circularity was higher and leaf length received lower values under non-frequent watering, in comparison to Drama (Table 2). 


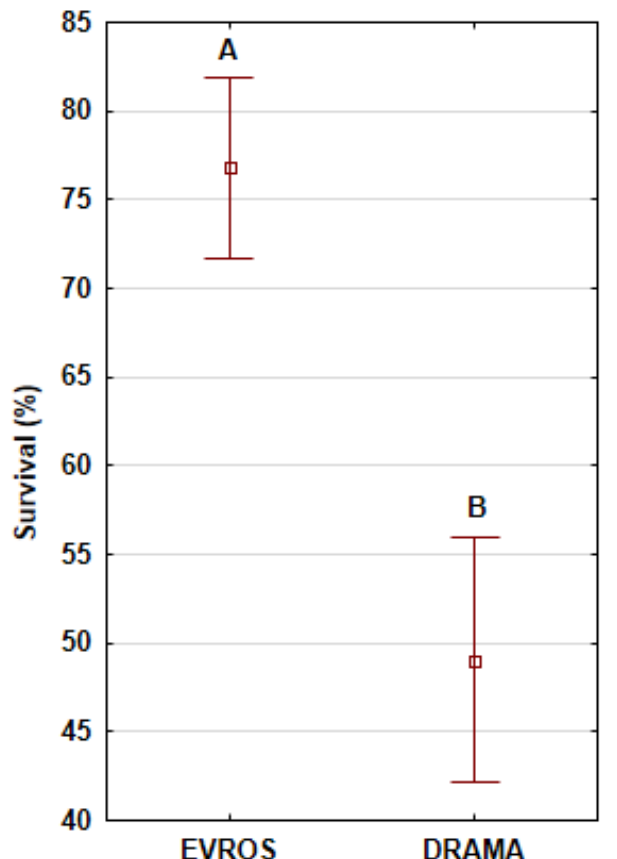

Watering scheme: NF

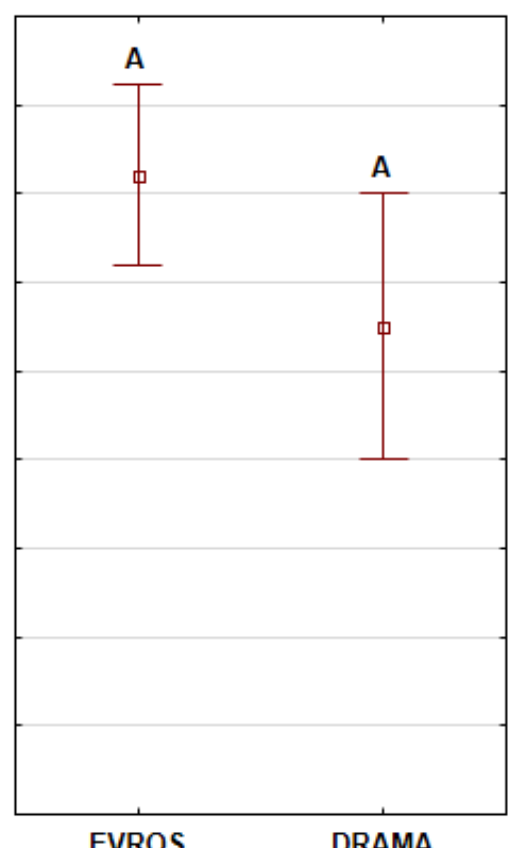

Watering scheme: FR
ㅁ Mean

IMean \pm SE

\section{Population}

Figure 2. Survival percentages of beech seedlings at the end of the experiment under each watering treatment. The vertical lines show the standard error of mean values. Mean values between populations followed by the same capital letter (separately for each watering treatment) do not statistically differ at $5 \%$ level of significance.

Table 2. Results of mixed model analysis for trait differentiations across watering treatments and populations.

\begin{tabular}{|c|c|c|c|}
\hline \multirow[t]{2}{*}{ Trait } & \multicolumn{3}{|c|}{ Factor } \\
\hline & Population & Watering Treatment & $\begin{array}{c}\text { Population } \times \text { Watering } \\
\text { Treatment }\end{array}$ \\
\hline Specific leaf area & 0.315 & 0.133 & 0.806 \\
\hline Leaf dry matter content & 0.757 & 0.216 & 0.146 \\
\hline Leaf thickness & 0.811 & 0.449 & 0.375 \\
\hline Leaf length & $0.002 *$ & 0.262 & 0.518 \\
\hline Leaf width & $0.005 *$ & 0.333 & 0.552 \\
\hline Leaf base angle & 0.517 & 0.716 & 0.153 \\
\hline Leaf tip angle & 0.083 & 0.801 & 0.454 \\
\hline Number of secondary leaf veins & 0.715 & 0.016 & 0.250 \\
\hline Leaf circularity & $0.025 *$ & $0.000 * * *$ & $0.001 * * *$ \\
\hline Shoot length & $0.005 * *$ & 0.200 & 0.601 \\
\hline Shoot dry weight & 0.142 & 0.342 & 0.200 \\
\hline Root area & 0.166 & 0.677 & 0.284 \\
\hline Root dry weight & 0.535 & 0.357 & 0.110 \\
\hline Section area & $0.000 * * *$ & 0.559 & $0.000 * * *$ \\
\hline Phellem length & 0.104 & 0.752 & 0.106 \\
\hline Cortex length & 0.727 & 0.465 & $0.001 * * *$ \\
\hline Phloem length & 0.064 & $0.040 *$ & $0.000 * * *$ \\
\hline Xylem length & 0.656 & 0.087 & $0.000 * * *$ \\
\hline Pith length & $0.002 * *$ & 0.214 & $0.000 * * *$ \\
\hline Stomatal number & $0.001 * * *$ & 0.521 & $0.008 * *$ \\
\hline Number of pith rays & 0.001 & 0.682 & 0.430 \\
\hline
\end{tabular}

Bold numbers represent significant differentiation $\left({ }^{* * *}, p<0.001 ;{ }^{* *}, p<0.01 ;{ }^{*}, p<0.05\right)$. 
Shoot length presented a marginal differentiation between populations, independent of the applied watering treatment, with Drama having higher values than Evros. Regarding stem anatomical traits, under non-frequent watering, Evros had lower leaf stomatal density, with thicker stem (i.e., higher section area) and higher cortex, phloem, xylem length and pith length than Drama. On the contrary, phellem length and the number of pith rays were the only anatomical traits showing no significant differentiation between populations under non-frequent watering, but they significantly differed under frequent watering. Phloem and xylem length were significantly different between populations at both non-frequent and frequent watering treatments. Under frequent watering, phloem, xylem and phellem length showed higher values in seedlings from Drama, while the number of pith rays was higher in Evros.

Furthermore, the results of the mixed model analysis showed a significant "population $\mathrm{x}$ watering treatment" interaction only for leaf circularity and most of the stem anatomical traits (i.e., section area, phloem length, xylem length, pith length and stomatal density) (Table 2). Finally, the PCA plot of individual trees clearly separated the Drama and Evros populations from each other under non-frequent watering, but not under frequent watering (Figure 3).

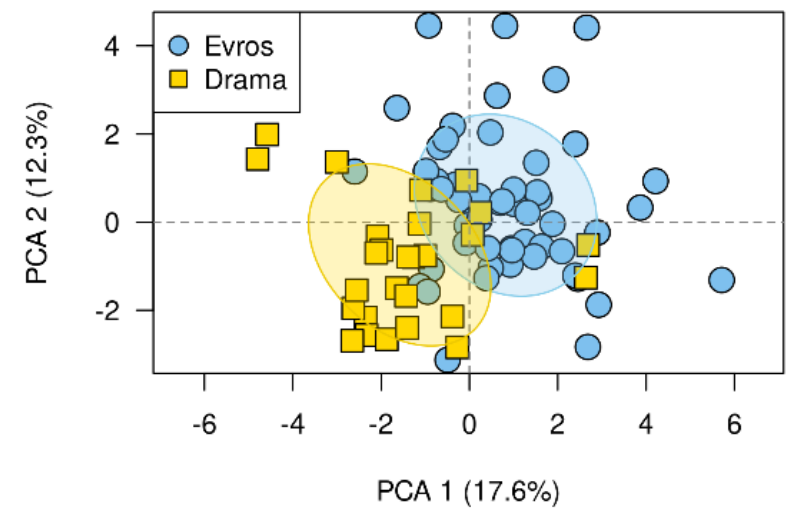

(a)

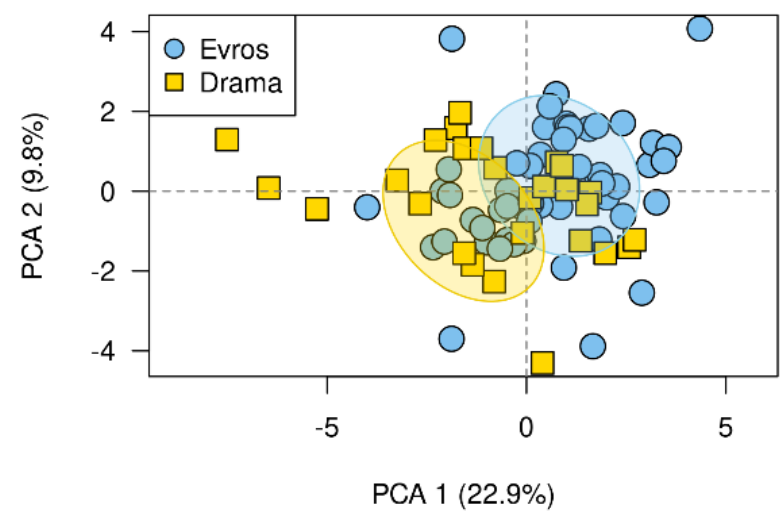

(b)

Figure 3. PCA plot of individuals, under (a) non-frequent and (b) frequent watering.

\section{Discussion}

\subsection{Seedling Response to Watering Frequency}

Our results demonstrate that watering frequency is an important parameter for beech seedling survival, even when the total amount of water provided remains constant. Nonfrequent watering seems to trigger phenotypic changes, especially in seedling stem and root anatomical traits, but this response was different across the studied beech populations.

Seedling survival at the end of the experiment was significantly affected by watering frequency. Survival percentage was lower for Drama seedlings under non-frequent than frequent watering, while in Evros survival did not differ between frequent and non-frequent watering. Thus, Evros proved to be more adapted to longer drought intervals than Drama and this could be attributed to adaptation to the environmental conditions of its site of origin, where precipitation seasonality and summer aridity are higher. It seems that even though the differences in precipitation of the driest quarter between Evros and Drama are small, they are still decisive for shaping seedling survival.

The only trait affected in a similar way for both populations was leaf circularity, while no significant changes due to the different watering treatments were recorded for the other leaf morphological traits. Non-frequent watering caused a significant decrease in leaf circularity, which indicates that seedlings reacted to long periods of drought by changing their leaf shape. Similarly, Xu et al. [79] report that the leaves of Quercus acutissima became 
narrower under drought because of limited watering, and a similar trend was reported by Granda et al. [35] in clones of Eucalyptus globulus.

A possible explanation for the overall lack of significant differences in beech leaf morphology under different watering frequencies may be a possible thermal stress that seedlings may have experienced during the experiment. The photosynthetic apparatus of beech is reported to be highly sensitive to thermal stress $[11,80]$, leading to the reduction of the available leaf surface to reduce photosynthetic activity of the plants, as a response [81-85]. Thus, we can assume that under a potential thermal stress under the controlled environment, the leaves became smaller and no further leaf size reduction was required for the seedlings to meet limitations by non-frequent watering.

The two beech populations studied, Evros and Drama, demonstrated contrasting seedling responses to different watering frequency treatments, at important adaptive traits. These traits include stomatal number in leaves and stem anatomical traits. When watering occurred less frequently, seedlings belonging to the Evros population had a significantly lower density of stomata on their leaves, which is a typical response of beech populations when transferred to drier and warmer climates [32]. The same treatment caused the opposite trend in seedlings from Drama, which thus had increased stomatal density on their leaves when watering occurred less frequently. This opposite response of Drama seedlings can be the result of adaptation to the prevailing precipitation pattern at their original environment during leaf development (Figure S1). Between spring and early summer, when leaves are growing, the monthly precipitation course follows a relatively uniform pattern, in contrast to Evros where it follows a continuous reduction until the end of summer.

A similar contrasting pattern between the two populations was observed when the anatomical traits for the stem vascular system and the overall structure of shoots and roots of the seedlings were compared for the two watering treatments. Non-frequent watering caused an increase in xylem, phloem, cortex, pith and phellem length among Evros seedlings, while the opposite trend was found in Drama. Thus, Evros seedlings produced more annual xylem and phloem under prolonged intervals between watering events resulting in a more robust vascular system with thicker xylem and phloem tissues, which possibly offers better protection against embolism and loss of cell turgor $[28,42,86]$. For the above protection path, the higher cortex can also contribute since it serves as sink tissue for low viscosity. The overall increase in stem thickness (higher section area) may also provide a more efficient water storage capacity for the seedlings [74]. The opposite was observed in seedlings belonging to Drama, where stem thickness was reduced, a response that was observed as a typical reaction of beech seedlings to drought $[87,88]$.

Subsequently, root and shoot dry weight of beech seedlings from Evros were found to be significantly greater under non-frequent irrigation than under the frequent watering treatment. Despite the fact that water deficit is expected to generally cause biomass reduction to beech seedlings $[87,89]$ and to root biomass in seedlings of the same tree species [58], the seedlings from Evros in our study demonstrated increased resource allocation in sink tissues under non-frequent watering. A possible explanation for this trend is the fact that the non-frequent watering treatment is not equivalent with the usually applied increased drought treatments. Additionally, biomass allocation to both root and shoot parts increases usually at mid-summer when precipitation is more scarce. It seems possible that the Evros seedlings, originating from a site where summer precipitation is less frequent and probably more unpredictable, better tolerated the higher watering interval, resulting in increased shoot and root biomass allocation. By contrast, seedlings from Drama followed the expected response against drought, thus demonstrating a moderate biomass reduction in their shoot and root tissues under the non-frequent watering treatment.

Furthermore, the root-to-shoot ratio was not affected in our case by the different watering treatments in each population, which agrees with other common environment studies for beech [24,89] and for Quercus robur [90]. However, Rose et al. [23] found a 
significant effect of water deficit on root/shoot ratio for beech populations in a common garden experiment.

\subsection{Adaptive Differences between Populations}

Under the simulated conditions of the year 2050 in the growth chamber, beech seedlings from Drama and Evros demonstrated differences in important adaptive traits. However, the only traits for which significant differences between the populations were observed, regardless of the watering treatment applied, were leaf size and shoot length. Drama seedlings had larger leaves and longer shoots than the ones from Evros. For most of the traits, and especially for the anatomical ones, the differences between the two populations followed different trends under the applied watering treatments, as explained above. Thus, the most noteworthy result of this experiment is the interaction between watering treatment and population, especially as far as the density of the leaf stomata, the stem anatomy and the overall biomass accumulated in shoots and roots is concerned.

These results strongly indicate that these two beech populations have adaptive differences towards the occurrence of longer drought periods caused by seasonal irregularities in precipitation. Despite receiving the same monthly amount of water, the distribution of monthly precipitation appears to have played a major role in the strategy followed by the seedlings of each population. Under less frequent water supply, seedlings from Drama seem to follow a conservative growth pattern by reducing their vascular area and decreasing stem growth, a typical drought avoidance reaction for temperate broadleaved trees [91,92]. Under the same conditions, seedlings from Evros seemingly invest more in better supporting their vascular system and acquire higher amounts of water and biomass gains when the resources are available, demonstrating an alternative strategy for coping with long drought intervals. In a review by Geßler et al. [1] it is reported that seasonal precipitation irregularities affect the growth of beech populations, while water-logged soils during spring for several regions due to higher-than-average precipitation could negatively impact the nutrient uptake and growth of beech. Thus, fewer but intense precipitations are potentially a stress factor for beech seedlings from Drama, but they seem to provide an opportunity for increased growth for beech seedlings from Evros.

\section{Conclusions}

The future of beech populations in the southern part of its distribution in Europe is uncertain, due to the climatic fluctuations that are expected to become more extreme in the next decades [93]. Pflug et al. [26], Gebauer et al. [58] and Larysch et al. [94] found high resilience of beech seedlings under spring drought, but they considered this resilience to be possibly weakened under repeated intense drought events, especially in the southernmost distributional limits of beech in Europe. However, beech populations on the southeastern part of Europe have demonstrated large genetic diversity $[95,96]$ and significant differentiation in adaptive traits $[18,19]$. The latter is further supported by our results, where seedlings seemed to cope with the effects of prolonged intervals between irrigation, following different adaptive strategies. While the seedlings from Evros showed a better survival under the 2050 conditions with longer drought intervals during summer, both populations demonstrated different strategies of plastic responses to these conditions, which have allowed the seedlings to finally survive for several years. Furthermore, these differences were evident under simulated climatic instability, with scarce, irregular and intense precipitation events, conditions that are expected to increase dramatically in the near future.

Our results indicate the existence of high adaptive potential as well as differentiation among populations in the rear edge of the beech distribution in Europe and demonstrate the importance of these populations for the future survival of beech in the continent, especially as far as management and conservation policies are concerned [97-99]. Populations of temperate species in the southern part of Europe are expected to suffer most under climate change, but they also demonstrate adaptive differences and high genetic diversity. Thus, 
these populations may become the basis for future common garden experiments further north, in regions where translocation of forest seed material is discussed as a measure to enrich genetic diversity locally and cope with the expected dramatic changes in climatic conditions in the continent. Understanding the adaptation mechanisms of plant populations from broader geographic regions is extremely important before making decisions about measures for conservation and management of tree genetic resources.

Supplementary Materials: The following are available online at https:/ /www.mdpi.com/article/10 $.3390 /$ biology11020306/s1, Figure S1: Precipitation at the original sites of the studied populations; Table S1: Bioclimatic variables at the original sites of the studied populations (downloaded and extracted from www.worldclim.org, accessed on 16 December 2021); Table S2: Values of climatic variables for study populations under CSIRO MK3.6 SRES A1B for the year 2050 (downloaded and extracted from www.climond.org, last accessed: 13 February 2013). Table S3: Descriptive statistics (mean value \pm standard error) of beech provenances under the applied watering treatments.

Author Contributions: Conceptualization, A.C.P., T.M. and I.T.; methodology, G.V., T.M., I.T. and P.G.D.; software, G.C.A. and G.V.; validation, T.M., I.T. and P.G.D.; formal analysis, K.T. and G.V.; investigation, all authors; resources, A.C.P., T.M., I.T. and P.G.D.; data curation, K.T., G.V. and A.C.P.; writing-original draft preparation, G.V., G.C.A. and A.C.P.; writing-review and editing, all authors; visualization, G.C.A. and G.V.; supervision, A.C.P., T.M., I.T. and P.G.D. All authors have read and agreed to the published version of the manuscript.

Funding: This research received no external funding.

Institutional Review Board Statement: Not applicable.

Informed Consent Statement: Not applicable.

Data Availability Statement: All data included in this study are available from corresponding authors, upon request.

Acknowledgments: We wish to thank A. Manolis for his support during sampling and laboratory work.

Conflicts of Interest: The authors declare no conflict of interest.

\section{References}

1. Geßler, A.; Keitel, C.; Kreuzwieser, J.; Matyssek, R.; Seiler, W.; Rennenberg, H. Potential Risks for European Beech (Fagus Sylvatica L.) in a Changing Climate. Trees 2007, 21,1-11. [CrossRef]

2. Michelot, A.; Simard, S.; Rathgeber, C.; Dufrêne, E.; Damesin, C. Comparing the Intra-Annual Wood Formation of Three European Species (Fagus Sylvatica, Quercus Petraea and Pinus Sylvestris) as Related to Leaf Phenology and Non-Structural Carbohydrate Dynamics. Tree Physiol. 2012, 32, 1033-1045. [CrossRef] [PubMed]

3. Ciais, P.; Reichstein, M.; Viovy, N.; Granier, A.; Ogée, J.; Allard, V.; Aubinet, M.; Buchmann, N.; Bernhofer, C.; Carrara, A.; et al. Europe-Wide Reduction in Primary Productivity Caused by the Heat and Drought in 2003. Nature 2005, 437, 529-533. [CrossRef] [PubMed]

4. Allen, C.D.; Macalady, A.K.; Chenchouni, H.; Bachelet, D.; McDowell, N.; Vennetier, M.; Kitzberger, T.; Rigling, A.; Breshears, D.D.; Hogg, E.H.; et al. A Global Overview of Drought and Heat-Induced Tree Mortality Reveals Emerging Climate Change Risks for Forests. For. Ecol. Manag. 2010, 259, 660-684. [CrossRef]

5. Fotelli, M.N.; Geßler, A.; Peuke, A.D.; Rennenberg, H. Drought Affects the Competitive Interactions between Fagus Sylvatica Seedlings and an Early Successional Species, Rubus Fruticosus: Responses of Growth, Water Status and $\delta 13$ C Composition. New Phytol. 2001, 151, 427-435. [CrossRef]

6. $\quad$ Leuschner, C.; Backes, K.; Hertel, D.; Schipka, F.; Schmitt, U.; Terborg, O.; Runge, M. Drought Responses at Leaf, Stem and Fine Root Levels of Competitive Fagussylvatica L. and Quercuspetraea (Matt.) Liebl. Trees in Dry and Wet Years. For. Ecol. Manag. 2001, 149, 33-46. [CrossRef]

7. Robson, T.M.; Calcerrada, J.R.; Sanchez-Gomez, D.; Aranda, I. Summer Drought Impedes Beech Seedling Performance more in a Sub-Mediterranean Forest Understory than in Small Gaps. Tree Physiol. 2008, 29, 249-259. [CrossRef]

8. Granier, A.; Reichstein, M.; Bréda, N.; Janssens, I.; Falge, E.; Ciais, P.; Grünwald, T.; Aubinet, M.; Berbigier, P.; Bernhofer, C.; et al. Evidence for Soil Water Control on Carbon and Water Dynamics in European Forests during the Extremely Dry Year. Agric. For. Meteorol. 2007, 143, 123-145. [CrossRef]

9. Bolte, A.; Czajkowski, T.; Kompa, T. The North-Eastern Distribution Range of European Beech-A Review. Forestry 2007, 80, 413-429. [CrossRef] 
10. Pšidová, E.; Ditmarová, L.; Jamnická, G.; Kurjak, D.; Majerová, J.; Czajkowski, T.; Bolte, A. Photosynthetic Response of Beech Seedlings of Different Origin to Water Deficit. Photosynthetica 2015, 53, 187-194. [CrossRef]

11. Leuschner, C. Drought Response of European Beech (Fagus Sylvatica L.)—A Review. Perspect. Plant Ecol. Evol. Syst. 2020, 47, 125576. [CrossRef]

12. Bréda, N.; Huc, R.; Granier, A.; Dreyer, E. Temperate Forest Trees and Stands under Severe Drought: A Review of Ecophysiological Responses, Adaptation Processes and Long-Term Consequences. Ann. For. Sci. 2006, 63, 625-644. [CrossRef]

13. Schuldt, B.; Buras, A.; Arend, M.; Vitasse, Y.; Beierkuhnlein, C.; Damm, A.; Gharun, M.; Grams, T.E.E.; Hauck, M.; Hajek, P.; et al. A First Assessment of the Impact of the Extreme 2018 Summer Drought on Central European Forests. Basic Appl. Ecol. 2020, 45, 86-103. [CrossRef]

14. Fotelli, M.N.; Nahm, M.; Radoglou, K.; Rennenberg, H.; Halyvopoulos, G.; Matzarakis, A. Seasonal and Interannual Ecophysiological Responses of Beech (Fagus sylvatica) at Its South-Eastern Distribution Limit in Europe. For. Ecol. Manag. 2009, 257, 1157-1164. [CrossRef]

15. Skrøppa, T.; Tollefsrud, M.M.; Sperisen, C.; Johnsen, Ø. Rapid Change in Adaptive Performance from One Generation to the Next in Picea Abies-Central European Trees in a Nordic Environment. Tree Genet. Genomes 2009, 6, 93-99. [CrossRef]

16. Sánchez-Gómez, D.; Robson, T.M.; Gascó, A.; Gil-Pelegrín, E.; Aranda, I. Differences in the Leaf Functional Traits of Six Beech (Fagus sylvatica L.) Populations Are Reflected in Their Response to Water Limitation. Environ. Exp. Bot. 2013, 87, 110-119. [CrossRef]

17. Pardos, M.; Calama, R. Responses of Pinus Pinea Seedlings to Moderate Drought and Shade: Is the Provenance a Differential Factor? Photosynthetica 2017, 56, 786-798. [CrossRef]

18. Varsamis, G.; Papageorgiou, A.C.; Merou, T.; Takos, I.; Malesios, C.; Manolis, A.; Tsiripidis, I.; Gailing, O. Adaptive Diversity of Beech Seedlings Under Climate Change Scenarios. Front. Plant Sci. 2019, 9, 1918. [CrossRef]

19. Varsamis, G.; Merou, T.; Takos, I.; Malesios, C.; Manolis, A.; Papageorgiou, A.C. Seed Adaptive Traits of Fagus Sylvatica Populations in Northeastern Greece. For. Sci. 2020, 66, 403-415. [CrossRef]

20. Bussotti, F.; Pollastrini, M.; Holland, V.; Brüggemann, W. Functional Traits and Adaptive Capacity of European Forests to Climate Change. Environ. Exp. Bot. 2015, 111, 91-113. [CrossRef]

21. De Villemereuil, P.; Gaggiotti, O.E.; Mouterde, M.; Till-Bottraud, I. Common Garden Experiments in the Genomic Era: New Perspectives and Opportunities. Heredity 2015, 116, 249-254. [CrossRef]

22. Huang, W.; Fonti, P.; Larsen, J.B.; Ræbild, A.; Callesen, I.; Pedersen, N.B.; Hansen, J. Projecting Tree-Growth Responses into Future Climate: A Study Case from a Danish-Wide Common Garden. Agric. For. Meteorol. 2017, 247, 240-251. [CrossRef]

23. Rose, L.; Leuschner, C.; Köckemann, B.; Buschmann, H. Are Marginal Beech (Fagus Sylvatica L.) Provenances a Source for Drought Tolerant Ecotypes? Forstwiss. Cent. 2009, 128, 335-343. [CrossRef]

24. Knutzen, F.; Meier, I.C.; Leuschner, C. Does Reduced Precipitation Trigger Physiological and Morphological Drought Adaptations in European Beech (Fagus sylvatica L.)? Comparing Provenances across a Precipitation Gradient. Tree Physiol. 2015, 35, 949-963. [CrossRef] [PubMed]

25. Stojnic, S.; Orlovic, S.; Miljkovic, D.; Von, W.G. Intra- and Interprovenance Variations in Leaf Morphometric Traits in European Beech (Fagus sylvatica L.). Arch. Biol. Sci. 2016, 68, 781-788. [CrossRef]

26. Pflug, E.E.; Buchmann, N.; Siegwolf, R.T.W.; Schaub, M.; Rigling, A.; Arend, M. Resilient Leaf Physiological Response of European Beech (Fagus sylvatica L.) to Summer Drought and Drought Release. Front. Plant Sci. 2018, 9, 187. [CrossRef] [PubMed]

27. Dannoura, M.; Epron, D.; Desalme, D.; Massonnet, C.; Tsuji, S.; Plain, C.; Priault, P.; Gérant, D. The Impact of Prolonged Drought on Phloem Anatomy and Phloem Transport in Young Beech Trees. Tree Physiol. 2018, 39, 201-210. [CrossRef]

28. Salmon, Y.; Dietrich, L.; Sevanto, S.; Hölttä, T.; Dannoura, M.; Epron, D. Drought Impacts on Tree Phloem: From Cell-Level Responses to Ecological Significance. Tree Physiol. 2019, 39, 173-191. [CrossRef]

29. Massonnet, C.; Chuste, P.-A.; Levillain, J.; Gérémia, F.; Silva, D.E.; Maillard, P.; Dreyer, E.; Dupouey, J.-L.; Bréda, N. Leafy Season Length Is Reduced by a Prolonged Soil Water Deficit but not by Repeated Defoliation in Beech Trees (Fagus sylvatica L.): Comparison of Response among Regional Populations Grown in a Common Garden. Agric. For. Meteorol. 2020, $297,108228$. [CrossRef]

30. Stojnić, S.; Orlović, S.; Miljković, D.; Galic, Z.; Kebert, M.; von Wuehlisch, G. Provenance Plasticity of European Beech Leaf Traits under Differing Environmental Conditions at Two Serbian Common Garden Sites. Forstwiss. Cent. 2015, 134, 1109-1125. [CrossRef]

31. Kucerová, J.; Konôpková, A.; Pšidová, E.; Kurjak, D.; Jamnická, G.; Slugenová, K.; Gömöry, D.; Ditmarová, L. Adaptive Variation in Physiological Traits of Beech Provenances in Central Europe. iFor. Biogeosci. For. 2018, 11, 24-31. [CrossRef]

32. Petrík, P.; Petek, A.; Konôpková, A.; Bosela, M.; Fleischer, P.; Frýdl, J.; Kurjak, D. Stomatal and Leaf Morphology Response of European Beech (Fagus Sylvatica L.) Provenances Transferred to Contrasting Climatic Conditions. Forests 2020, 11, 1359. [CrossRef]

33. Magnani, F.; Grace, J.; Borghetti, M. Adjustment of Tree Structure in Response to the Environment under Hydraulic Constraints. Funct. Ecol. 2002, 16, 385-393. [CrossRef]

34. Mokotedi, M.E. Physiological Responses of Eucalyptus Nitens $\times$ Nitensunder Experimentally Imposed Water Stress. South. For. J. For. Sci. 2010, 72, 63-68. [CrossRef] 
35. Granda, V.; Delatorre, C.; Cuesta, C.; Centeno, M.L.; Fernández, B.; Rodríguez, A.; Feito, I. Physiological and Biochemical Responses to Severe Drought Stress of Nine Eucalyptus Globulus Clones: A Multivariate Approach. Tree Physiol. 2014, 34, 778-786. [CrossRef]

36. Ledo, A.; Paul, K.I.; Burslem, D.; Ewel, J.J.; Barton, C.V.M.; Battaglia, M.; Brooksbank, K.; Carter, J.; Eid, T.H.; England, J.R.; et al. Tree Size and Climatic Water Deficit Control Root to Shoot Ratio in Individual Trees Globally. New Phytol. 2017, $217,8-11$. [CrossRef]

37. Mrak, T.; Štraus, I.; Grebenc, T.; Gričar, J.; Hoshika, Y.; Carriero, G.; Paoletti, E.; Kraigher, H. Different Belowground Responses to Elevated Ozone and Soil Water Deficit in Three European Oak Species (Quercus ilex, Q. Pubescens and Q. Robur). Sci. Total Environ. 2018, 651, 1310-1320. [CrossRef]

38. Seleiman, M.F.; Al-Suhaibani, N.; Ali, N.; Akmal, M.; Alotaibi, M.; Refay, Y.; Dindaroglu, T.; Abdul-Wajid, H.H.; Battaglia, M.L. Drought Stress Impacts on Plants and Different Approaches to Alleviate Its Adverse Effects. Plants 2021, 10, 259. [CrossRef]

39. Corcuera, L.; Camarero, J.J.; Gil-Pelegrín, E. Effects of a Severe Drought on Quercus ilex Radial Growth and Xylem Anatomy. Trees 2003, 18, 83-92. [CrossRef]

40. Lens, F.; Sperry, J.S.; Christman, M.A.; Choat, B.; Rabaey, D.; Jansen, S. Testing Hypotheses That Link Wood Anatomy to Cavitation Resistance and Hydraulic Conductivity in the Genus Acer. New Phytol. 2010, 190, 709-723. [CrossRef]

41. Lens, F.; Tixier, A.; Cochard, H.; Sperry, J.S.; Jansen, S.; Herbette, S. Embolism Resistance as a Key Mechanism to Understand Adaptive Plant Strategies. Curr. Opin. Plant Biol. 2013, 16, 287-292. [CrossRef]

42. Sevanto, S. Phloem Transport and Drought. J. Exp. Bot. 2014, 65, 1751-1759. [CrossRef]

43. Nardini, A.; Savi, T.; Trifilò, P.; Gullo, M.A.L. Drought Stress and the Recovery from Xylem Embolism in Woody Plants. In Progress in Botany; Springer: Cham, Switzerland, 2017; pp. 197-231. [CrossRef]

44. Klein, T.; Zeppel, M.J.B.; Anderegg, W.R.L.; Bloemen, J.; De Kauwe, M.G.; Hudson, P.; Ruehr, N.K.; Powell, T.L.; von Arx, G.; Nardini, A. Xylem Embolism Refilling and Resilience against Drought-Induced Mortality in Woody Plants: Processes and Trade-Offs. Ecol. Res. 2018, 1-17. [CrossRef]

45. Rouphael, Y.; Cardarelli, M.; Schwarz, D.; Franken, P.; Colla, G. Effects of Drought on Nutrient Uptake and Assimilation in Vegetable Crops. In Plant Responses to Drought Stress: From Morphological to Molecular Features; Aroca, R., Ed.; Springer: Berlin/Heidelberg, Germany, 2012; ISBN 978-3-642-32653-0.

46. Rosell, J.A.; Olson, M.E. The Evolution of Bark Mechanics and Storage across Habitats in a Clade of Tropical Trees. Am. J. Bot. 2014, 101, 764-777. [CrossRef]

47. Rosell, J.A. Bark Thickness across the Angiosperms: More than Just Fire. New Phytol. 2016, 211, 90-102. [CrossRef]

48. Nilsen, E.T.; Bao, Y. The Influence of Water Stress on Stem and Leaf Photosynthesis in Glycine Max and Sparteum junceum (Leguminosae). Am. J. Bot. 1990, 77, 1007-1015. [CrossRef]

49. Barbaroux, C.; Breda, N. Contrasting Distribution and Seasonal Dynamics of Carbohydrate Reserves in Stem Wood of Adult Ring-Porous Sessile Oak and Diffuse-Porous Beech Trees. Tree Physiol. 2002, 22, 1201-1210. [CrossRef]

50. Pfanz, H. Bark Photosynthesis. Trees 2008, 22, 137-138. [CrossRef]

51. Ávila, E.; Herrera, A.; Tezara, W. Contribution of Stem $\mathrm{CO}_{2}$ Fixation to Whole-Plant Carbon Balance in Nonsucculent Species. Photosynthetica 2013, 52, 3-15. [CrossRef]

52. Paul, S.; Wildhagen, H.; Janz, D.; Polle, A. Drought Effects on the Tissue- and Cell-Specific Cytokinin Activity in Poplar. AoB Plants 2017, 10, plx067. [CrossRef] [PubMed]

53. Mijnsbrugge, K.V.; Turcsán, A.; Erdélyi, É.; Beeckman, H. Drought Treated Seedlings of Quercus Petraea (Matt.) Liebl., Q. Robur L. and Their Morphological Intermediates Show Differential Radial Growth and Wood Anatomical Traits. Forests 2020, 11, 250. [CrossRef]

54. Tognetti, R.; Michelozzi, M.; Borghetti, M. Response to Light of Shade-Grown Beech Seedlings Subjected to Different Watering Regimes. Tree Physiol. 1994, 14, 751-758. [CrossRef]

55. Tognetti, R.; Johnson, J.D.; Michelozzi, M. The Response of European Beech (Fagus sylvatica L.) Seedlings from Two Italian Populations to Drought and Recovery. Trees 1995, 9, 348-354. [CrossRef]

56. Gallé, A.; Feller, U. Changes of Photosynthetic Traits in Beech Saplings (Fagus Sylvatica) under Severe Drought Stress and during Recovery. Physiol. Plant. 2007, 131, 412-421. [CrossRef]

57. Zang, U.; Goisser, M.; Häberle, K.-H.; Matyssek, R.; Matzner, E.; Borken, W. Effects of Drought Stress on Photosynthesis, Rhizosphere Respiration, and Fine-Root Characteristics of Beech Saplings: A Rhizotron Field Study. Z. Pflanz. Bodenk. 2014, 177, 168-177. [CrossRef]

58. Gebauer, R.; Plichta, R.; Urban, J.; Volařík, D.; Hájiččková, M. The Resistance and Resilience of European Beech Seedlings to Drought Stress during the Period of Leaf Development. Tree Physiol. 2020, 40, 1147-1164. [CrossRef]

59. Kunz, J.; Räder, A.; Bauhus, J. Effects of Drought and Rewetting on Growth and Gas Exchange of Minor European Broadleaved Tree Species. Forests 2016, 7, 239. [CrossRef]

60. Barigah, T.S.; Charrier, O.; Douris, M.; Bonhomme, M.; Herbette, S.; Ameglio, T.; Fichot, R.; Brignolas, F.; Cochard, H. Water Stress-Induced Xylem Hydraulic Failure Is a Causal Factor of Tree Mortality in Beech and Poplar. Ann. Bot. 2013, 112, $1431-1437$. [CrossRef] 
61. Bolte, A.; Czajkowski, T.; Cocozza, C.; Tognetti, R.; De Miguel, M.; Pšidová, E.; Ditmarová, L.; Dinca, L.; Delzon, S.; Cochard, H.; et al. Desiccation and Mortality Dynamics in Seedlings of Different European Beech (Fagus sylvatica L.) Populations under Extreme Drought Conditions. Front. Plant Sci. 2016, 7, 751. [CrossRef]

62. Cocozza, C.; De Miguel, M.; Pšidová, E.; Ditmarová, L.; Marino, S.; Maiuro, L.; Alvino, A.; Czajkowski, T.; Bolte, A.; Tognetti, R. Variation in Ecophysiological Traits and Drought Tolerance of Beech (Fagus sylvatica L.) Seedlings from Different Populations. Front. Plant Sci. 2016, 7, 886. [CrossRef]

63. Wang, F.; Israel, D.; Ramírez-Valiente, J.-A.; Sánchez-Gómez, D.; Aranda, I.; Aphalo, P.J.; Robson, T.M. Seedlings from Marginal and Core Populations of European Beech (Fagus sylvatica L.) Respond Differently to Imposed Drought and Shade. Trees 2020, 35, 53-67. [CrossRef]

64. Brooks, H. Severe Thunderstorms and Climate Change. Atmos. Res. 2013, 123, 129-138. [CrossRef]

65. Papageorgiou, A.C.; Vidalis, A.; Gailing, O.; Tsiripidis, I.; Hatziskakis, S.; Boutsios, S.; Galatsidas, S.; Finkeldey, R. Genetic Variation of Beech (Fagus sylvatica L.) in Rodopi (N.E. Greece). Forstwiss. Cent. 2007, 127, 81-88. [CrossRef]

66. Müller, M.; Lopez, P.A.; Papageorgiou, A.C.; Tsiripidis, I.; Gailing, O. Indications of Genetic Admixture in the Transition Zone between Fagus sylvatica L. and Fagus Sylvatica ssp. Orientalis Greut. \& Burd. Diversity 2019, 11, 90. [CrossRef]

67. ISTA. Chapter 5: The Germination Test. In Rules Proposal for the International Rules for Seed Testing; International Rules Seed Testing: Bassersdorf, Switzerland, 2017; pp. 1-62. [CrossRef]

68. Syktus, J.; Jeffrey, S.; Rotstayn, L.; Wong, K.; Toombs, N.; Dravitzki, S.; Collier, M.; Hamalainen, C.; Moeseneder, C. The CSIROQCCCE Contribution to CMIP5 Using the CSIRO Mk3.6 Climate Model. In Proceedings of the MODSIM 2011-19th International Congress on Modelling and Simulation-Sustaining Our Future: Understanding and Living with Uncertainty; The Modelling and Simulation Society of Australia and New Zealand: Perth, Australia, 2011; pp. 2782-2788.

69. Kriticos, D.J.; Webber, B.L.; Leriche, A.; Ota, N.; Macadam, I.; Bathols, J.; Scott, J.K. CliMond: Global High-Resolution Historical and Future Scenario Climate Surfaces for Bioclimatic Modelling. Methods Ecol. Evol. 2012, 3, 53-64. [CrossRef]

70. Radoglou, K.; Jarvis, P.G. Effects of $\mathrm{CO}_{2}$ Enrichment on Four Poplar Clones. II. Leaf Surface Properties. Ann. Bot. 1990, 65, 627-632. [CrossRef]

71. Bussotti, F.; Prancrazi, M.; Matteucci, G.; Gerosa, G. Leaf Morphology and Chemistry in Fagus Sylvatica (Beech) Trees as Affected by Site Factors and Ozone: Results from CONECOFOR Permanent Monitoring Plots in Italy. Tree Physiol. 2005, 25, 211-219. [CrossRef]

72. Cornelissen, J.H.C.; Lavorel, S.; Garnier, E.; Díaz, S.; Buchmann, N.; Gurvich, D.E.; Reich, P.; Ter Steege, H.; Morgan, H.D.; Van Der Heijden, M.G.A.; et al. A Handbook of Protocols for Standardised and Easy Measurement of Plant Functional Traits Worldwide. Aust. J. Bot. 2003, 51, 335-380. [CrossRef]

73. Vile, D.; Garnier, É.; Shipley, B.; Laurent, G.; Navas, M.-L.; Roumet, C.; Lavorel, S.; Díaz, S.; Hodgson, J.G.; Lloret, F.; et al. Specific Leaf Area and Dry Matter Content Estimate Thickness in Laminar Leaves. Ann. Bot. 2005, 96, 1129-1136. [CrossRef]

74. Jupa, R.; Plavcová, L.; Gloser, V.; Jansen, S. Linking Xylem Water Storage with Anatomical Parameters in Five Temperate Tree Species. Tree Physiol. 2016, 36, 756-769. [CrossRef]

75. Bissing, D.R. Haupt's Gelatin Adhesive Mixed with Formalin for Affixing Paraffin Sections to Slides. Stain Technol. 1974, 49, 116-117. [CrossRef] [PubMed]

76. Edward, C.; Yeung, A. Beginner's Guide to the Study of Plant Structure. In Proceedings of the Tested Studies for Laboratory Teaching; Karcher, J.S., Ed.; Association for Biology Laboratory Education: Irvine, CA, USA, 1998; pp. 125-142.

77. Crang, R.; Lyons-Sobaski, S.; Wise, R. The Nature of Plants. In Plant Anatomy; Springer International Publishing: Cham, Switzerland, 2018; pp. 3-44.

78. Lê, S.; Josse, J.; Husson, F. FactoMineR: AnRPackage for Multivariate Analysis. J. Stat. Softw. 2008, 25, 1-18. [CrossRef]

79. Xu, F.; Guo, W.; Xu, W.; Wang, R. Habitat Effects on Leaf Morphological Plasticity in Quercus Acutissima. Acta Biol. Crac. Ser. Bot. 2008, 50, 19-26.

80. Peltzer, D. Anpassung Antioxidativer Systeme an Licht und Temperatur: Holzige und Krautige Pflanzen im Vergleich; Georg-AugustUniversität Göttingen: Göttingen, Germany, 2001.

81. Haldimann, P.; Feller, U. Inhibition of Photosynthesis by High Temperature in Oak (Quercus pubescens L.) Leaves Grown under Natural Conditions Closely Correlates with a Reversible Heat-Dependent Reduction of the Activation State of Ribulose-1,5Bisphosphate Carboxylase/Oxygenase. Plant Cell Environ. 2004, 27, 1169-1183. [CrossRef]

82. Takahashi, S.; Murata, N. How Do Environmental Stresses Accelerate Photoinhibition? Trends Plant Sci. 2008, 13, 178-182. [CrossRef]

83. Hüve, K.; Bichele, I.; Rasulov, B.; Niinemets, Ü.L.O. When It Is Too Hot for Photosynthesis: Heat-Induced Instability of Photosynthesis in Relation to Respiratory Burst, Cell Permeability Changes and $\mathrm{H}_{2} \mathrm{O}_{2}$ Formation. Plant Cell Environ. 2010, 34, 113-126. [CrossRef]

84. Gururani, M.A.; Venkatesh, J.; Tran, L.S.P. Regulation of Photosynthesis during Abiotic Stress-Induced Photoinhibition. Mol. Plant 2015, 8, 1304-1320. [CrossRef]

85. Leigh, A.; Sevanto, S.; Close, J.; Nicotra, A. The Influence of Leaf Size and Shape on Leaf Thermal Dynamics: Does Theory Hold Up under Natural Conditions? Plant Cell Environ. 2016, 40, 237-248. [CrossRef]

86. Pfautsch, S.; Holtta, T.; Mencuccini, M. Hydraulic Functioning of Tree Stems-Fusing Ray Anatomy, Radial Transfer and Capacitance. Tree Physiol. 2015, 35, 706-722. [CrossRef] 
87. Schall, P.; Lödige, C.; Beck, M.; Ammer, C. Biomass Allocation to Roots and Shoots is More Sensitive to Shade and Drought in European Beech than in Norway Spruce Seedlings. For. Ecol. Manag. 2012, 266, 246-253. [CrossRef]

88. Cuervo-Alarcon, L.; Arend, M.; Müller, M.; Sperisen, C.; Finkeldey, R.; Krutovsky, K.V. A Candidate Gene Association Analysis Identifies SNPs Potentially Involved in Drought Tolerance in European Beech (Fagus sylvatica L.). Sci. Rep. 2021, $11,2386$. [CrossRef]

89. Robakowski, P.; Wyka, T.; Kowalkowski, W.; Barzdajn, W.; Pers-Kamczyc, E.; Jankowski, A.; Politycka, B. Practical Implications of Different Phenotypic and Molecular Responses of Evergreen Conifer and Broadleaf Deciduous Forest Tree Species to Regulated Water Deficit in a Container Nursery. Forests 2020, 11, 1011. [CrossRef]

90. Zadworny, M.; Mucha, J.; Jagodziński, A.M.; Kościelniak, P.; Łakomy, P.; Modrzejewski, M.; Ufnalski, K.; Żytkowiak, R.; Comas, L.H.; Rodríguez-Calcerrada, J. Seedling Regeneration Techniques Affect Root Systems and the Response of Quercus Robur Seedlings to Water Shortages. For. Ecol. Manag. 2020, 479, 118552. [CrossRef]

91. Borchert, R.; Pockman, W. Water Storage Capacitance and Xylem Tension in Isolated Branches of Temperate and Tropical Trees. Tree Physiol. 2005, 25, 457-466. [CrossRef]

92. Brunner, I.; Herzog, C.; Dawes, M.A.; Arend, M.; Sperisen, C. How Tree Roots Respond to Drought. Front. Plant Sci. 2015, 6, 547. [CrossRef]

93. del Río, S.; Álvarez-Esteban, R.; Cano, E.; Pinto-Gomes, C.; Penas, Á. Potential Impacts of Climate Change on Habitat Suita-bility of Fagus sylvatica L. Forests in Spain. Plant Biosyst. 2018, 152, 1205-1213. [CrossRef]

94. Larysch, E.; Stangler, D.F.; Nazari, M.; Seifert, T.; Kahle, H.-P. Xylem Phenology and Growth Response of European Beech, Silver Fir and Scots Pine along an Elevational Gradient during the Extreme Drought Year 2018. Forests 2021, 12, 75. [CrossRef]

95. Gömöry, D.; Paule, L.; Brus, R.; Zhelev, P.; Tomović, Z.; Gračan, J. Genetic Differentiation and Phylogeny of Beech on the Balkan Peninsula. J. Evol. Biol. 1999, 12, 746-754. [CrossRef]

96. Hatziskakis, S.; Papageorgiou, A.C.; Gailing, O.; Finkeldey, R. High Chloroplast Haplotype Diversity in Greek Populations of Beech (Fagus sylvatica L.). Plant Biol. 2009, 11, 425-433. [CrossRef]

97. Mátyás, C.; Bozic, G.; Gömöry, D.; Ivankovic, M.; Rasztovits, E. Juvenile Growth Response of European Beech (Fagus sylvatica L.) to Sudden Change of Climatic Environment in SE European Trials. iFor. Biogeosci. For. 2009, 2, 213-220. [CrossRef]

98. Lefèvre, F.; Boivin, T.; Bontemps, A.; Courbet, F.; Davi, H.; Durand-Gillmann, M.; Fady, B.; Gauzere, J.; Gidoin, C.; Karam, M.-J.; et al. Considering Evolutionary Processes in Adaptive Forestry. Ann. For. Sci. 2013, 71, 723-739. [CrossRef]

99. Fady, B.; Cottrell, J.; Ackzell, L.; Alía, R.; Muys, B.; Prada, A.; González-Martínez, S.C. Forests and Global Change: What Can Genetics Contribute to the Major Forest Management and Policy Challenges of the Twenty-First Century? Reg. Environ. Chang. 2015, 16, 927-939. [CrossRef] 